\title{
SCORE CARDS FOR EVALUATION OF RFI AND RFP PROCESSES WITHIN ONE OF THE BULGARIAN TELECOMMUNICATION OPERATORS
}

\begin{abstract}
Avgustin Milanov ${ }^{1}$
Received: 05.09.2020, Accepted: 27.09.2020

Abstract

The present paper regards some the score cards as a possible tool for measurement and evaluation of the risk in the "Request for Information" (RFI) and "Request for Proposal" (RFP) processes in the supply chain at the Bulgarian mobile telecommunication operators. The presented hereby score cards use measurement and calculations of the risk based on the risk calculation equation in which the assumption is that each risk event or risk action " $m$ " can be regarded as function of the likelihood of occurrence, the consequences and the imminence in regards to the time horizon for the occurrence of the very same risk event or risk action " $m$ ". Further to these components, the risk equation in use also takes into account the space in which the risk occurs and itself, as well as the size of the actions for prevention and overcoming of the risks that can appear at a certain organizational level. The data collected for the score cards is being provided by an online survey through the staff dealing with the RFI and RFP processes within the regarded in particular Bulgarian telecommunication operator. The final information from both the survey and the score cards is being processed and turned into a specific set of numeric coefficients that represent the contribution and the value of the separate risk components. Methods for defining the thresholds for acceptance of the levels of the risks are also suggested.
\end{abstract}

Keywords: score cards, supply chain management, risk management, risk evaluation, RFI and RFP process, telecommunication operators

JEL Codes: L93, O18, F47

\section{Introduction}

The present paper regards some the score cards as a possible tool for measurement and evaluation of the risk in the "Request for Information" (RFI) and "Request for Proposal" (RFP) processes in the supply chain at the Bulgarian

${ }^{1}$ Department of Economics, Faculty of Economics, South-West University "Neofit Rilski”, PhD candidate, e-mail: avgustin.milanov@gmail.com,

ORCID ID: https://orcid.org/0000-0002-9968-7273 
mobile telecommunication operators. These approaches include measurement and calculations of the risk based on the use of risk calculation equation and questionnaire surveys and follow-up score cards. The proposed in the paper risk calculation equation is based on the assumption that each risk event or risk action " $\mathrm{m}$ " can be regarded as function of the likelihood of occurrence, the consequences and the imminence in regards to the time horizon for the occurrence of the very same risk event or risk action " $m$ ". Further to these components, the risk equation in use also takes into account the space in which the risk occurs and develops itself, as well as the size of the actions for prevention and overcoming of the risk at the certain organizational level. The data collected from the questionnaire surveys and score cards are being processed and turned into a specific set of numeric coefficients that represent the contribution and the value of the separate risk components. Methods for defining the thresholds for acceptance of the levels of the risks are also suggested. The present paper regards also several more specific problems in the application of the risk measurement and evaluation the RFI and RFP process in supply chain of the Bulgarian mobile telecommunication operators such the use of the risk evaluation for the point of time when the forecasts of the major indicators of the RFI RFP processes suggest a major future decline.

\section{Literature review and some basic concept notes}

The present paper's approach for the risk measurement and evaluation, which differs significantly to the one used in the traditional financial management, dates back to 1989 when it was proposed by R. N. Charrette for the purposes of software engineering risk analysis and management. What Charrette proposed was actually to measure the risk by the use of the following risk assessment and evaluation equation:

\section{(1.) $\mathbf{R}(\mathrm{m})=\mathrm{L}(\mathrm{m}) \times \mathbf{C}(\mathrm{m}) \times \mathbf{I}(\mathrm{m})$,}

Where:

$\mathbf{L}(\mathbf{m})$ is the likelihood of occurrence of the risk event or action " $m$ ";

C(m) stands the consequences from the occurrence of the risk event or action " $m$ ", and

$\mathbf{I}(\mathbf{m})$ is the imminence for of the risk event or action " $\mathrm{m}$ " in regards to the time horizon. 
The problem of risk measurement and evaluation in RFI and RFP in the mobile telecommunication operators is a part of the broader problem of measuring the risk at business process level within the organizations. All business processes produce certain risks (Reilly et al., 2016), which are usually regarded by managers in terms of technical performance, cost, and schedule. In a more holistic approach, the risks within the organization are also regarded as "business risks". And according to a survey conducted once by "Arthur Anderson" and "The Economist" and cited by Turner and Hunsucker, "business risk" is defined as, "the threat that an event or action will adversely affect the organizations ability to achieve its business objectives and execute its strategies effectively" ("The Economist"). Having into consideration the concept of the "Request For Information" (RFI) and "Request for Proposal" (RFP) processes in the supply chain at the mobile telecommunication operators as business risks, one can easily apply many of the existing (financial by the nature) methodologies for quantifying and measuring the business risks and their components. Most of these methodologies, however, suffer, from one main disadvantage: they present risk either as a standard deviation of a certain indicator across an average value, or present some understanding for the risk components which is not clearly explicit and/or does not include all of these very same risk components. The present paper adapts focuses on a particular methodology for measuring the occupational health and safety risks in tourism companies by numerical risk coefficients and use of risk evaluation score cards. Beside the initial work or R. N. Cahrette, this methodology was thoroughly explained also by John V. Turner and John L. Hunsucker in an article named "Effective risk management: a global based approach", published in "International Journal of Technology Management". It includes the achievements of several US and international research and innovation development programs, such as:

"SSP" ("Space Shuttle Program);

"ISSP" ("International Space Station Program);

"F/A-18" (a project of the US Department of Defense); and

"AFMC" (US Air Force Material Command).

Later on, this methodology was adapted and implemented for the needs of risk management within the innovation process of the Bulgarian travel and tourism companies, mainly from the sub-sector of the hotel industry in regards to the risk management in tourism innovation processes and risk management in health and safety in tourism companies. The adapted by Dimitrov model for the risk evaluation and assessment in the hotel industry based on variables of the likelihood (Lm) of occurrence of the risk event or action " $\mathrm{m}$ ", the consequences 
$(\mathrm{Cm})$ from the occurrence of the risk event or action " $\mathrm{m}$ ", and imminence (Im) for of the risk event or action " $\mathrm{m}$ " in regards to the time horizon was enhances by A. Hristozova in 2012 for the needs of the insurance activities in the travel and tourism industry by adding a component regarding the space of the risk event or action.

\section{(2) $\quad \mathbf{R}(\mathrm{m})=\mathrm{L}(\mathrm{m}) \times \mathrm{C}(\mathrm{m}) \times \mathbf{I}(\mathrm{m}) \times \mathrm{S}(\mathrm{m})$}

A similar methodology was also presented in 2003 by Dimitar Dimitrov and Erdoan Hadzhiev for the need of the risks analysis on the working place and in the labor processes in the transport sector. Dimitrov and Hadziev's methodology differs from Turner and Hunsucker's concept only in the names of the main variables comprising the risk function and in the scaling of these variables which will be explained further on. They also propose a ready to use questionnaire for the purposes of the transport sector in Bulgaria instead of developing of an Integrated Risk Consequences Scorecard.

\section{Methodology and main results}

For the needs of the research that stands for the present paper, as well as taking into account of the extremely dynamic development of the sector of the mobile telecommunication operators both globally and in Bulgaria, and the resulting from this dynamic development of their supply chains, it becomes necessary the suggest by Charrette, Turner \& Hunsucker, Dimitrov and Hristozova risk assessment and evaluation equation to be modified significantly. This modification refers to adding two more components, two more variables that influence with a negative sign the value of the risks with the businesses processes. These two components are the scale of the actions for the risk preventions and the risk aversions $(\operatorname{Pr}(\mathrm{m})$ and the scale of overcoming the consequences of the risks in case of their occurrence. In this regards, the risk assessment and evaluation equation, wherein the variables are being calculated by the use of scorecards, finally result in the following mathematical notation (3):

\section{(3) $\quad \mathrm{R}(\mathrm{m})=\mathrm{L}(\mathrm{m}) \times \mathrm{C}(\mathrm{m}) \times \mathbf{I}(\mathrm{m}) \times \mathrm{S}(\mathrm{m})-\mathrm{P}(\mathrm{m}) \times \mathbf{O}(\mathrm{m})$.}

This modified risk equation plays a central role in construction of the methodology of the survey, the results of which are being reported in the present paper. As for the separate stages of the survey itself they are seven in number, as 
follows: (i) an online questionnaire to be answered and filled in by the employers engaged in the two departments involved heavily in the RFI and RFP processes: (ii) a follow-up scorecard resulting survey for each of the components (variables) of the risk assessment and evaluation equation; (iii) calculation of the value of the risk in the RFI and RFP processes; (iv)applying of criteria for acceptance or non-acceptance of the RFI and RFP connected business risks; (v) taking of "Go / Not go decisions" for the usual flow of the RFI and RFP processes; (vi) forecasting the parameters of the usual flow of the RFI and RFP processes; and (vii) anticipating and planning the next measurement, assessment and evaluation and the "Go / Not Go" decision points. These very same seven stages represent a process not only for measurement, assessment and evaluation of the risks in RFI and RFP processes in the supply chain of one of the Bulgarian mobile telecommunication operators, but an overall pro-active risk management concept aimed at managing, averting, reducing and anticipating the respected business risks (Figure 1).

The pro-activeness of the suggested risk management concept is the presence of "Go / Not Go" decisions points in line with forecasting of the main parameters of the usual flow of the RFI and the RFP processes in order to anticipate the needs for next risk measurement, assessment and evaluation and next "Go/ Not Go" decision points. Here, it has to be pointed out that this concepts steps to the modular approach for risk management in development of new products suggested by R. G. Cooper and R. A. More (Cooper \& More, 1997) and it develop further this very same approach by adding the forecasting component. 
Figure no. 1. The flow chart of the survey and the suggest risk management concept:

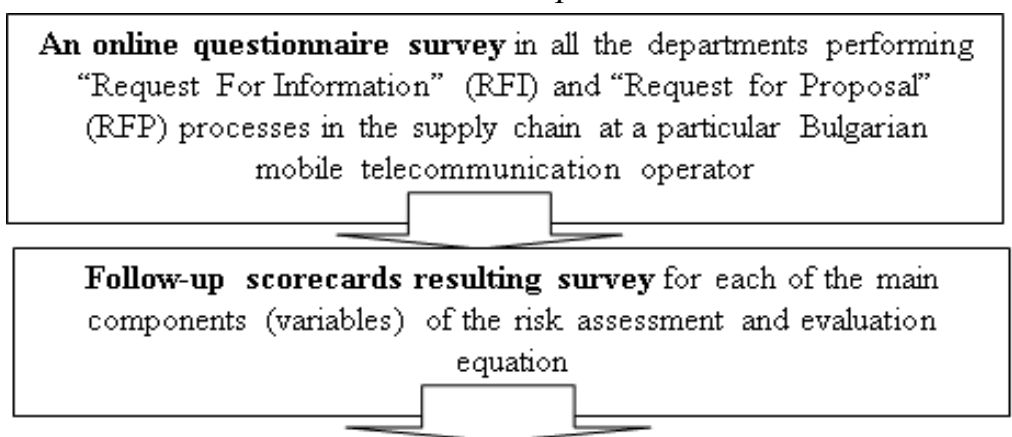

Calculation of the value of the risk in the RFI and the RFP process in the supply chain in the regarded mobile telecommunication operator
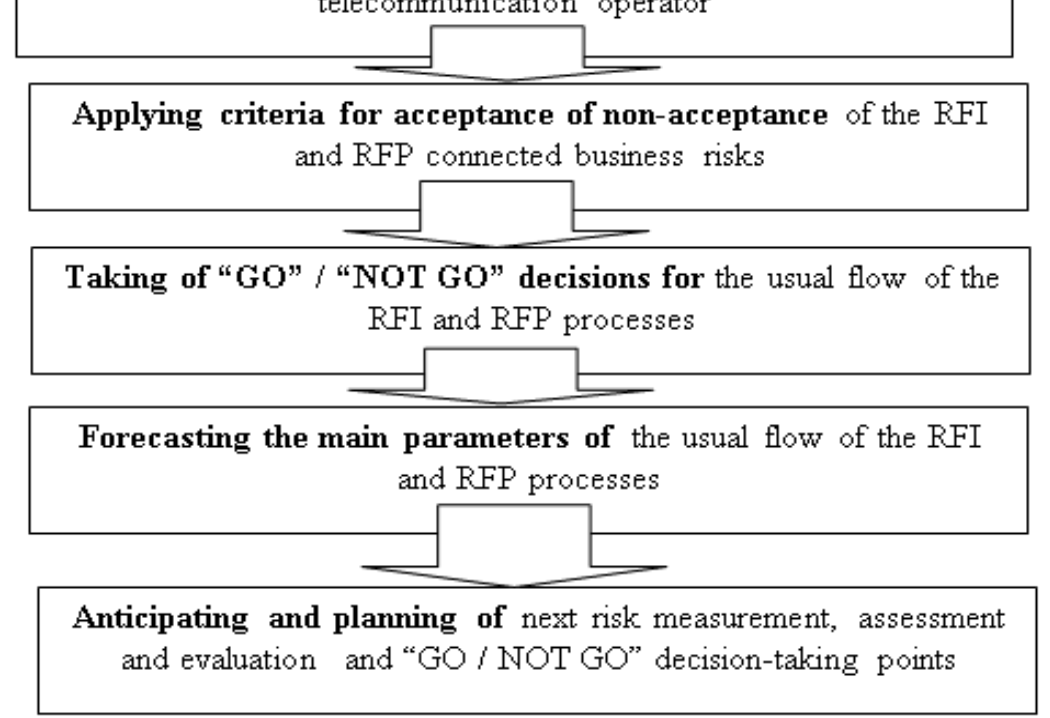

Source: Authors' own drawing

For the performing the risk measurement, assessment and evaluation stage an online Google-based questionnaire in Bulgarian language was constructed comprising 20 questions, including a few related to the parameters of the studied population and the predominant part directly or indirectly related to the variable in the risk assessment and evaluation equation (Figure 2). 
The questions directly or indirectly related to the components (to the variables) of the risk assessment and evaluation equation included the following questions:

1. How many times do you encounter problems in fulfilling a supply contract within the usual two-year period?

2. What is the effect of the consequences on your department's or company's activities on the problems encountered in executing a delivery contract?

3. How quickly after the conclusion of a supply contract problems appear?

4. If there is a delay in delivery, it is for the following reasons?

5. In case of problems with the supplier, the problem that has arisen most often affects the activity of?

6. What is the most common delivery problem?

7. What is the most urgent proposal for change or improvement you would offer to improve supply?

8. Does your direct supervisor provide you with the necessary support or assistance to resolve a supply problem?

9. Does the management guide provide you with the necessary support or assistance in the event of a supply problem?

10. Does the department have the necessary and sufficient human and expert resources to solve supply problems?

11. Does the department have the necessary and sufficient financial resources?

12. Does the department work with the necessary autonomy and authority to resolve supply problems?

The multiple answers under most of the above questions have been used for constructing of risk evaluation scorecards (Tables from Table 1 to Table 14). 
Table 1. Score card for evaluation of the likelihood for the realization of the risk action or event " $m$ ":

\begin{tabular}{|r|r|r|r|l|}
\hline $\begin{array}{c}\text { Question } \\
\text { No.9 }\end{array}$ & Possible answers: & $\begin{array}{c}\text { Evaluation of } \\
\text { the likelihood } \\
\text { component in } \\
\text { score points }\end{array}$ & $\begin{array}{c}\text { Relative } \\
\text { weight if the } \\
\text { evaluation }\end{array}$ & $\begin{array}{c}\text { Weighted } \\
\text { evaluation }\end{array}$ \\
\hline & Not a once & 0 & 0,3 & 0 \\
\hline & $\begin{array}{r}\text { Tetwice } \\
\text { five times }\end{array}$ & 2 & 0,1 & 0,2 \\
\hline & More than five times & 10 & 0,3 & 1,2 \\
\hline & $\begin{array}{r}\text { Again, it depends on } \\
\text { the situation }\end{array}$ & 5 & 0 & 0 \\
\hline & $\begin{array}{r}\text { I do not work with } \\
\text { contracts }\end{array}$ & 0 & 0,1 & 0,5 \\
\hline & $\begin{array}{r}\text { There contract with } \\
\text { problems and } \\
\text { another ones without } \\
\text { any problems }\end{array}$ & 5 & 0,1 & 0 \\
\hline $\begin{array}{r}\text { Average weighted } \\
\text { coefficient of the } \\
\text { risk likelihood }\end{array}$ & & 0,1 & 0,5 \\
\hline
\end{tabular}

Table 2. Score card for evaluation of the consequences of the realization of the

\begin{tabular}{|c|c|c|c|c|}
\hline $\begin{array}{c}\text { Question } \\
\text { No.10 }\end{array}$ & Possible answers: & $\begin{array}{l}\text { Evaluation of } \\
\text { the likelihood } \\
\text { component in } \\
\text { score points }\end{array}$ & $\begin{array}{c}\text { Relative weight } \\
\text { of the } \\
\text { evaluation }\end{array}$ & $\begin{array}{l}\text { Weighted } \\
\text { evaluation }\end{array}$ \\
\hline & None & 0 & 0 & 0 \\
\hline & Very weak & 1 & 0,18 & 0,18 \\
\hline & More likely weak & 3 & 0 & 0 \\
\hline & Moderate & 5 & 0 & 0 \\
\hline & $\begin{array}{r}\text { More likely } \\
\text { strong }\end{array}$ & 7 & 0,45 & 3,15 \\
\hline & Strong & 10 & 0,09 & 0,9 \\
\hline & $\begin{array}{r}\text { Average weighted } \\
\text { coefficient of the } \\
\text { risk } \\
\text { consequences: }\end{array}$ & & $C(m)$ & 4,23 \\
\hline
\end{tabular}


Table 3. Score card for the evaluation of imminence "Im"

\begin{tabular}{|r|r|r|r|l|}
\hline $\begin{array}{c}\text { Question } \\
\text { No.11 }\end{array}$ & $\begin{array}{c}\text { Average weighted } \\
\text { coefficient of the risk } \\
\text { imminence }\end{array}$ & $\begin{array}{c}\text { Evaluation of the } \\
\text { imminence } \\
\text { components in } \\
\text { score points: }\end{array}$ & $\begin{array}{c}\text { Relative weight } \\
\text { of the evaluation }\end{array}$ & $\begin{array}{c}\text { Weighted } \\
\text { evaluation }\end{array}$ \\
\hline & $\begin{array}{r}\text { Up to one month } \\
\text { Between one or } \\
\text { two months }\end{array}$ & 1 & 0,33 & 0,33 \\
\hline & $\begin{array}{r}\text { Between two or } \\
\text { three months }\end{array}$ & 5 & 0 & 0 \\
\hline & $\begin{array}{r}\text { More than three } \\
\text { months }\end{array}$ & 7 & 0,167 & 1,169 \\
\hline & $\begin{array}{r}\text { "The good answer } \\
\text { predicts itself" } \\
\text { (not predefined } \\
\text { answer) }\end{array}$ & 0 & & 0 \\
\hline & $\begin{array}{r}\text { "I cannot tell } \\
\text { exactly" }\end{array}$ & 0 & 0,167 & 0 \\
\hline & $\begin{array}{r}\text { "It depends on } \\
\text { each separate } \\
\text { case" }\end{array}$ & 0 & 0,167 & 0 \\
\hline & $\begin{array}{r}\text { Average weighted } \\
\text { coefficient of the } \\
\text { risk imminence }\end{array}$ & & $\mathbf{I}(\mathbf{m})$ & $\mathbf{1 , 4 9 9}$ \\
\hline
\end{tabular}

Table 4. Score card for evaluation of the first part of the space component (S1) for the realization of the risk action or event - ,S(m)"

\begin{tabular}{|r|r|l|r|l|}
\hline $\begin{array}{c}\text { Question } \\
\text { No.12 }\end{array}$ & Possible answers & $\begin{array}{c}\text { Evaluation of the } \\
\text { space component } \\
\text { in score points }\end{array}$ & $\begin{array}{c}\text { Relative } \\
\text { weight of the } \\
\text { evaluation }\end{array}$ & $\begin{array}{c}\text { Weighted } \\
\text { evaluation }\end{array}$ \\
\hline & $\begin{array}{r}\text { Remoteness of the } \\
\text { supplier }\end{array}$ & 2 & 0,125 & 0,25 \\
\hline & $\begin{array}{r}\text { Geographical } \\
\text { remoteness }\end{array}$ & 0 & 0 & 0 \\
\hline $\begin{array}{r}\text { Limitations } \\
\text { connected with } \\
\ldots . . .\end{array}$ & 2 & 0,125 & 0,25 \\
\hline & $\begin{array}{r}\text { Problems with the } \\
\text { transportation }\end{array}$ & 4 & 0,25 & 1 \\
\hline & $\begin{array}{r}\text { Each case is a } \\
\text { separate one }\end{array}$ & 2 & 0,125 & 0,25 \\
\hline
\end{tabular}




\begin{tabular}{|r|r|l|r|l|}
\hline & $\begin{array}{r}\text { Problems in the } \\
\text { supplier }\end{array}$ & 2 & 0,125 & 0,25 \\
\hline & $\begin{array}{r}\text { Everything stated } \\
\text { above }\end{array}$ & 2 & 0,125 & 0,25 \\
\hline & $\begin{array}{r}\text { The problems are } \\
\text { miscellaneous }\end{array}$ & 2 & 0,125 & 0,25 \\
\hline & $\begin{array}{r}\text { Average weighted } \\
\text { coefficient of the } \\
\text { risk space } \\
\text { componente }\end{array}$ & $\mathbf{S ( m )}$ & $\mathbf{2 , 5}$ \\
\hline
\end{tabular}

Table 5. Score card for evaluation of the second part of the space component $(S 2)$ for the realization of the risk action or event - ,S(m)"

\begin{tabular}{|l|r|l|r|l|}
\hline $\begin{array}{c}\text { Questions } \\
\text { No.13 }\end{array}$ & Possible answers & $\begin{array}{c}\text { Evaluation of the } \\
\text { space component in } \\
\text { score points }\end{array}$ & $\begin{array}{c}\text { Relative weight } \\
\text { of the } \\
\text { evaluation }\end{array}$ & $\begin{array}{c}\text { Weighted } \\
\text { evaluation }\end{array}$ \\
\hline & $\begin{array}{r}\text { The activity of } \\
\text { your department }\end{array}$ & 0 & 0 & 0 \\
\hline $\begin{array}{r}\text { The activity of } \\
\text { both department }\end{array}$ & 2 & 0,111 & 0,222 \\
\hline & $\begin{array}{r}\text { The activities of } \\
\text { more than 2 } \\
\text { departments }\end{array}$ & 7 & 0,667 & 4,669 \\
\hline $\begin{array}{r}\text { The whole } \\
\text { company }\end{array}$ & 3 & 0,222 & 0,666 \\
\hline & $\begin{array}{r}\text { Average weighted } \\
\text { coefficient of the } \\
\text { risk space } \\
\text { componente }\end{array}$ & $\mathbf{S ( m )}$ & $\mathbf{5 , 5 5 7}$ \\
\hline
\end{tabular}

Table 6. A summation table for evaluation of the space component for the realization of the risk action or event,,$- S(m)$ " $(S=S 1$ (№12)) $+S 2$ (№13))

\begin{tabular}{|c|rr|r|}
\hline S1 & \multicolumn{2}{|c|}{ S2 } & \multicolumn{2}{c|}{ S } \\
\hline 2,5 & & 5,557 & 8,057 \\
\hline
\end{tabular}


Table 7. Score card for evaluation of actions for overcoming of the risk part of the risk prevention and risk aversion actions $(O v 1)$ :

\begin{tabular}{|r|r|r|r|l|}
\hline $\begin{array}{c}\text { Question } \\
\text { No.16 }\end{array}$ & Possible answers & $\begin{array}{c}\text { Evaluation of } \\
\text { the adequacy of } \\
\text { preventions in } \\
\text { score points }\end{array}$ & $\begin{array}{c}\text { Relative weight } \\
\text { of the evaluation }\end{array}$ & $\begin{array}{c}\text { Weighted } \\
\text { evaluation }\end{array}$ \\
\hline & Always & 1 & 0,889 & 0,889 \\
\hline & Often & 0 & 0 & 0 \\
\hline & Sometimes & 5 & 0,111 & 0,555 \\
\hline & Rarely & 0 & 0 & 0 \\
\hline & Very rarely & 0 & 0 & 0 \\
\hline & $\begin{array}{c}\text { Weighted average } \\
\text { coefficient of the } \\
\text { risk overcoming }\end{array}$ & & $\boldsymbol{O} \mathbf{v}(\boldsymbol{m})$ & $\mathbf{1 , 4 4}$ \\
\hline
\end{tabular}

Table 8. Score card for evaluation of the actions for overcoming of the risk

$(O v \cdot 2)$ :

\begin{tabular}{|r|r|r|r|l|}
\hline $\begin{array}{c}\text { Question } \\
\text { No.17 }\end{array}$ & Possible answers & $\begin{array}{c}\text { Evaluation foe } \\
\text { the risk } \\
\text { overcoming in } \\
\text { score points }\end{array}$ & $\begin{array}{c}\text { Relative weight } \\
\text { of the evaluation }\end{array}$ & $\begin{array}{c}\text { Weighted } \\
\text { evaluation }\end{array}$ \\
\hline & Always & 1 & 0,667 & 0,667 \\
\hline & Often & 3 & 0,333 & 0,999 \\
\hline & Sometimes & 0 & 0 \\
\hline & Rarely & 0 & 0 \\
\hline & $\begin{array}{r}\text { Wery rarely } \\
\text { coefficient of the } \\
\text { risk overcoming }\end{array}$ & & 0 & 0 \\
& & $\mathbf{O v}(\mathbf{m})$ & $\mathbf{1 , 6 6 6}$ \\
\hline
\end{tabular}

Table 9. Score card for evaluation of part of the risk prevention and risk aversion actions (Prl):

\begin{tabular}{|r|r|r|r|l|}
\hline $\begin{array}{c}\text { Question } \\
\text { No.18 }\end{array}$ & Possible answers & $\begin{array}{c}\text { Evaluation of the } \\
\text { adequacy of } \\
\text { prevention in } \\
\text { score points }\end{array}$ & $\begin{array}{c}\text { Relative weight } \\
\text { of the evaluation }\end{array}$ & $\begin{array}{c}\text { Weighted } \\
\text { evaluation }\end{array}$ \\
\hline & Always & 2 & 0,556 & 1,112 \\
\hline & Often & 4 & 0,111 & 0,444 \\
\hline & Sometimes & 6 & 0,333 & 1,998 \\
\hline & Rarely & 0 & 0 & 0 \\
\hline & Very rarely & 0 & 0 & 0 \\
& $\begin{array}{r}\text { Adequacy of the } \\
\text { prevention } \\
\text { measures }\end{array}$ & & $\operatorname{Pr1(m)}$ & $\mathbf{3}, \mathbf{5 5 4}$ \\
\hline
\end{tabular}


Table 10. Score card for evaluation of part of the risk prevention and risk aversion actions (Pr2):

\begin{tabular}{|c|c|c|c|c|}
\hline $\begin{array}{l}\text { Questions } \\
\text { No. } 19\end{array}$ & Possible answers & $\begin{array}{c}\text { Evaluation of } \\
\text { the adequacy of } \\
\text { the risk } \\
\text { prevention } \\
\text { measures in } \\
\text { score points } \\
\end{array}$ & $\begin{array}{c}\text { Relative weight } \\
\text { of the } \\
\text { evaluation }\end{array}$ & $\begin{array}{c}\text { Weighted } \\
\text { evaluation }\end{array}$ \\
\hline & Always & 1 & 0,111 & 0,111 \\
\hline & Often & 2 & 0,222 & 0,444 \\
\hline & Sometimes & 5 & 0,333 & 1,665 \\
\hline & Rarely & 7 & 0,111 & 0,777 \\
\hline & Very rarely & 0 & 0 & 0 \\
\hline & $\begin{array}{r}\text { Scattered } \\
\text { distribution of } \\
\text { answers } \\
\end{array}$ & 2 & 0,111 & 0,222 \\
\hline & No & 10 & 0,111 & 1,11 \\
\hline & $\begin{array}{r}\text { Adequacy of the } \\
\text { prevention } \\
\text { measures and } \\
\text { actions }\end{array}$ & & $\operatorname{Pr}(\mathbf{m})$ & 4,329 \\
\hline
\end{tabular}

Table 11. Score card for evaluation of the actions for overcoming of the risk

(Ov.3):

\begin{tabular}{|r|r|r|r|l|}
\hline $\begin{array}{c}\text { Question } \\
\text { No.20 }\end{array}$ & Possible answers & $\begin{array}{c}\text { Evaluation of the } \\
\text { adequacy of } \\
\text { prevention in } \\
\text { score points }\end{array}$ & $\begin{array}{c}\text { Relative weight } \\
\text { of the evaluation }\end{array}$ & $\begin{array}{c}\text { Weighted } \\
\text { evaluation }\end{array}$ \\
\hline & Always & 1 & 0,1 & 0,1 \\
\hline & Often & 3 & 0,6 & 1,8 \\
\hline & Sometimes & 5 & 0,1 & 0,5 \\
\hline & Rarely & 7 & 0,1 & 0,7 \\
\hline & Very rarely & 9 & 0,1 & 0,9 \\
\hline & Risk overcoming & & $\mathbf{O v}(\mathbf{m})$ & 4 \\
\hline
\end{tabular}

Table 12. Score card summation table for evaluation of the action on the risk prevention and aversion $\operatorname{Pr}(m)=\operatorname{Pr}(m) 1($ No.18)) $+\operatorname{Pr}(m) 2(N o .19))$

\begin{tabular}{|c|c|c|}
\hline $\operatorname{Pr}(\mathrm{m}) 1$ & $\operatorname{Pr}(m) 2$ & $\operatorname{Pr}(\mathbf{m})$ \\
\hline 3,554 & 4,329 & 7,883 \\
\hline
\end{tabular}


Table 13. Score card summation table for evaluation of the actions on overcoming of the risk consequences in case of its realization $O v(m)$,

(m)) =Question No.(16)+Question No.(17)+Question No.(20)

\begin{tabular}{|c|r|c|c|}
\hline Question No.16 & Question No.17 & Question No.20 & Ov(m) \\
\hline 1,444 & 1,666 & 4 & 7,11 \\
\hline
\end{tabular}

Table 14. Table of the final evaluation of the risk with the date from the questionnaire survey $R(m)=L(m) * C(m) * I(m) * S(m)-(\operatorname{Pr}(m) * O v(m))$ :

\begin{tabular}{|c|c|c|c|c|c|c|}
\hline $\mathbf{L}(\mathbf{m})$ & $\mathbf{C}(\mathbf{m})$ & $\mathbf{I}(\mathbf{m})$ & $\mathbf{S}(\mathbf{m})$ & $\operatorname{Pr}(\mathbf{m})$ & $\mathbf{O v}(\mathbf{m})$ & $\mathbf{R}(\mathbf{m})$ \\
\hline 2,40 & 4,23 & 1,499 & 8,06 & 7,883 & 7,11 & 66,56207 \\
\hline
\end{tabular}

Based on results from the questionnaire survey and the follow-up scorecard resulting survey, a calculation of the value of the business risk or business risks can be performed by the use of the risk assessment and evaluation equation:

(4) $\quad \mathbf{R}(m)=L(m) \times C(m) \times I(m) \times S(m)-(\operatorname{Pr}(m) \times \mathbf{O v}(m))$,

Where:

Weighted average risk probability coefficient $\mathrm{L}(\mathrm{m})=2,40$

Consequences $\mathrm{C}(\mathrm{m})=4.23$

Imminence I $(\mathrm{m})=1.499$

Spatial component $\mathrm{S}(\mathrm{m})=8.57$

The risk prevention component $\operatorname{Pr}(\mathrm{m})=3.554$

The risk overcoming component $\mathrm{Ov}(\mathrm{m})=7,883$

The overall risk $(\mathrm{R}(\mathrm{m})$ ) calculation achieved by a direct substitution in the equation of the above-listed variables is as follows (See also Table 14):

$R(m)=\mathbf{L}(m) * C(m) * I(m) * S(m)-(\operatorname{Pr}(m) * O v(m))=$

$=2.40 * 1.499 * 1.499 * 8.57-3.554 * 7.833=102.4007754$.

\section{Conclusion}

The presented methodology for risk assessment and evaluation and the overall concept for risk management by the use of digital risk evaluation coefficients has led to a significant improve in the performance of the departments within the Bulgarian mobile telecommunication operator in concern 
with the supply chain management and with the RFI and RFP processes in particular. The mere fact of taking into consideration that the everyday business risk may be numerically measured has led to a decrease in the level of risks and the "GO / NOT TO GO" decision-taking point have added to the improved of the risk reduction, risk aversion, risk transfer and risk prevention actions with the company. The forecasting of appropriate moments for "GO / NOT TO GO" decision-taking points on the basis of the minimums of the main parameters of the RFI and the RFP processes have also added to the further refining of the suggested risk management implementation model.

\section{References:}

Brinkley, R. \& Stone, D. (1996). International Space Station Program Directive - Program Risk Management Emphasis System”, ISS-PD-011, NASA, Johnson Space Center, Houston, Texas, USA.

Brooks, W. M. (1994). Project Risk Management (a presentation given at Johnson Space Center, May 9-11, 1994), Johnson Space Center, and Huston, Texas, USA.

Brown, R. G. (1959). Statistical Forecasting for Inventory Control. New York: McGraw-Hill.

Charette, R. N. (1989). Software Engineering Risk Analysis and Management, New York, USA: Intertext Publications, McGraw-Hill Book Company.

Chatfield, C. \&Yar, M. (1988). Holt-Winters forecasting: Some practical issues. The Statistician, 37, pp. 129-140.

DeLurgio, S. A. (1998). Forecasting Principles and Applications. Pennsylvania State University: Irwin/McGraw-Hill.

Dimitrov, D. \& Hadzhiev, E. (2003). Analysis of Place of Work and Labour Process Risk in Transport. Scientific Journal "Mechanics, Transport, Communication”, Issue: 1/2003, Article No. 0007, Retrieved January 21, 2019 from http://www.mtc-aj.com

Dimitrov, P. (2003). Risk Management in Tourism Innovations. Sofia, Bulgaria: Heron Press.

Dimitrov, P. (2006). Tourism Innovations. Blagoevgrad, Bulgaria: "Neofit Rilski" University Press.

Dimitrov, P. (2009). Measuring occupational health and safety risks in tourism companies. EgeAkademikBakışDergisi, Turkey.

Hamilton, J .D. (1994). Time Series Analysis. Princeton, NJ: Princeton University Press. 
Hayan, J. A. (1996). F/A-18 "Risk management plan", Report MDC 960074, McDonnel Douglas Aerospace, St. Luis, USA

Holt, C. C. (1957). Forecasting trends and seasonals by exponentially weighted averages, O.N.R. Memorandum 52/1957, Carnegie Institute of Technology.

Hyndman, R. J., Koehler, A.B., Ord, J.K. \& Snyder, R.D. (2008). Forecasting with Exponential Smoothing - The State Space Approach. Berlin: Springer.

The Economist (1996). A Game of Risk - The Economist Survey, Corporate Risk Management, 10th February, 1996; 